\title{
Biological and Economic Efficiency of Radish (Raphanus sativus L.) Intercropped with Vegetable Amaranthus (Amaranthus tricolor L.)
}

\author{
T.H. Seran* and I. Brintha*
}

Department of Crop Science, Faculty of Agriculture, Eastern University of Sri Lanka, Vantharumoolai, Sri Lanka

\begin{abstract}
A field experiment was conducted at the Agronomy farm, Eastern University, Sri Lanka to study the biological and economic efficiency of radish (Raphanus sativus L.) intercropped with vegetable amaranthus (Amaranthus tricolor L.). Treatments were radish as sole crop (T1), vegetable amaranthus as sole crop (T2), 20/50 cm paired row radish with three (T3) or four (T4) rows of vegetable amaranthus in between paired rows and $25 / 40 \mathrm{~cm}$ paired row radish with three (T5) or two (T6) rows of vegetable amaranthus in between paired rows. The results showed that, there was no significant difference $(\mathrm{P}>0.05)$ in area time equivalency ratio (ATER) among intercropping treatments and significant differences $(\mathrm{P}<0.05)$ were obtained in the land equivalent ratio (LER) and crop performance ratio $(\mathrm{CPR})$. LER (1.31) and CPR (1.71) were superior in T3 and T4 respectively. In case of economic indices, gross return was significantly differed $(\mathrm{P}<0.01)$ among treatments. It was high in $\mathrm{T} 3$ followed by $\mathrm{T} 4$. Intercropping system recorded significantly high $(\mathrm{P}<0.01)$ cost of cultivation over intercropping system. Among intercropping, T4 resulted maximum net return, monetary equivalent ratio, cost benefit ratio and per day return over other intercropping treatments and sole crops. This experiment revealed that $\mathrm{T} 4$ would be the most efficient system in both biological and economical point of view.
\end{abstract}

\section{INTRODUCTION}

The economies of many tropical countries are based on agricultural crops [1]. Increasing population in developing countries leads to reduce arable land and increase the demand of agriculture products. The only way to increase agricultural production in the small or marginal units of farming is to increase the productivity per unit time and area [2]. Intercropping is defined as cultivating two or more crops in the same land area at the same time. It is one of the ways to increase crop production per unit area. Intercropping leads to efficient utilization of the farm resource and to increase crop production per unit area per unit time. Also by intercropping, different varieties of products can be produced throughout the year, greater stability of yield from season to season than sole cropping and reduction in pest and disease attacks. Modification of planting pattern of the base crop would make intercropping feasible and remunerative to farmers for successful intercropping. The modified system affords a better solar energy harvest in the space between two of crops. Intercropping can increase light interception by as much as $30-40 \%$ [2]. Development of feasible and economically viable intercropping system largely depends on the adaptation of planting pattern and selection of compatible crops.

Radish (Raphanus sativus L.) and vegetable amaranthus (Amaranthus tricolor L.) are important vegetables in Sri Lanka. Radish is an edible root vegetable of the Brassicaceae family that can be grown in all agro ecological regions of Sri Lanka throughout the year if adequate moisture is available.

*Address correspondence to these authors at the Department of Crop Science, Faculty of Agriculture, Eastern University of Sri Lanka, Vantharumoolai, Sri Lanka; Tel: 0094-65-2240760; Fax: 0094-65-2240740;

E-mails: ilbrintha@yahoo.co.in and thayaseran@yahoo.com
It is a popular choice for cultivation, as they are fairly easy to grow, rapidly maturing crop with many varieties able to reach maturity within 60 days. Radish is a popular vegetable in both tropical and temperate regions and used as vegetable or salad in Sri Lanka. Radish provides considerable amount of nutrients, especially rich in protein, fat, carbohydrate, fiber and ash, calcium, sodium, phosphorus and potassium [3]. Both roots and leaves of radish are a good source of calcium, phosphorus and ascorbic acid [4]. Radishes are not only cooked but they have medicinal and industrial values as well. It is useful in the treatment of several diseases namely, gall bladder troubles, sleepleness, chronic diaria, neuralgic headaches, urinary complaints, piles and gastrodynia [4]. In nut shell, radish is an important plant in both nutritional and medicinal aspects.

Vegetable amaranthus (Amaranthus tricolor L.) is widely grown in the tropics and is one of the most important leafy vegetable in Asia under family Amaranthaceae. It is an annual, fast growing plant and is easily cultivated in gardens and field. It is a good source of protein (high in lysine and methionine), vitamin and mineral, especially rich in iron, calcium, vitamins A and C [5]. Iron deficiency is a sever problem in developing countries associated with health and survival of children, is controlled by consume amaranthus leaves. Also it has vitamin A, which is vital to the millions of malnourished children now at risk of blindness. Vegetable amaranthus is used to lower blood pressure and to aid in elimination.

Vegetable crops absorb large amount of nutrients [6]. Radish needs higher amount of potassium for tuberous root formation. On the contrary, nitrogen is vital for leafy vegetable production. By intercropping radish with vegetable amaranthus, a more efficient use of fertilizer is achieved. Opti- 
mum time of harvest in most types of amaranthus is $25-30$ days after sowing to get highest yield as well as nutritious and palatable greens [7] while radish can harvest 45-60 days after sowing which leads to reduce competition for resources at peak production. These two crops, which matures at different times, there by separating their periods of maximum demand for nutrient and moisture, aerial space and light could be suitably intercropped [8]. Therefore, radish and vegetable amaranthus are compatible crops for intercropping.

For a farmer, higher income may be more essential than higher crop yields [9]. Evaluating cropping system is important to select superiority over the existing system adapted by the framers in terms of biological productivity and economic potential for particular area. No single index is capable of evaluating cropping system. Commonly biological and economic indices are used to identify the production technologies. Agronomist decides biological efficiency based on indices such as land equivalent ratio, area time equivalency ratio, cropping intensity index, while economist should decide the economic worthiness of the system using economic indices [10]. In general, a biological efficient system is also economically superior, but economic efficiency of superior depends on the cost of input and price of produces [10]. Economic value is pertinent only to the location and time for which computation based. Its real value changes greatly over time and for different location. However, selected cropping system is good for that particular area until new system would be proofed it's superiority. Therefore, an attempt was made to evaluate the biological and economic efficiency of radish (Raphanus sativus L.) intercropped with vegetable amaranthus (Amaranthus tricolor L.) in sandy regosol.

\section{METHODOLOGY}

A field study was conducted at the Agronomy farm, Eastern University, Sri Lanka for two seasons, 2007/2008 to study the biological and economic efficiency of radish (Raphanus sativus L.) intercropped with vegetable amaranthus (Amaranthus tricolor L.). The Agronomy farm is situated at Eastern region, Sri Lanka between $81^{\circ} 34^{\prime}$ latitude and longitude and $7^{\circ} 48^{\prime}$ longitude. It comes under the agro ecological zones of low country dry zone. The soil of experimental site is sandy regosol.

This experiment was laid out in a Randomized Complete Block Design with six treatments and four replication with a $1.2 \mathrm{~m} \times 1.8 \mathrm{~m}$ plot size. A spacing of $0.5 \mathrm{~m}$ separated the plot from each other and a space of $1 \mathrm{~m}$ wide separated the blocks from each other. Vegetable amaranthus, CV red variety and radish CV Japan ball variety were used for this attempt. Treatments were radish as a sole crop with the spacing of $30 \mathrm{~cm} \times 10 \mathrm{~cm}(\mathrm{~T} 1)$, vegetable amaranthus as a sole crop with the spacing of $10 \mathrm{~cm} \times 5 \mathrm{~cm}(\mathrm{~T} 2), 20 / 50 \mathrm{~cm}$ paired row planting $(20 \mathrm{~cm}$ distance between rows in a pair and 50 $\mathrm{cm}$ distance between two paired rows) of radish with three rows (T3) or four rows (T4) of vegetable amaranthus in between paired rows of radish and $25 / 40 \mathrm{~cm}$ paired row planting $(25 \mathrm{~cm}$ distance between rows in a pair and $40 \mathrm{~cm}$ distance between two paired rows). of radish with three rows (T5) or two rows (T6) of vegetable amaranthus in between paired rows of radish. In intercropping, distance between radish in paired row and vegetable amaranthus is $15 \mathrm{~cm}$ in $\mathrm{T} 3$ and $\mathrm{T} 6$ and $10 \mathrm{~cm}$ in T4 and T5.
Prior to sowing, the germination test was done and the germination percentages of radish and vegetable amaranthus seed stocks were $85 \%$ and $89 \%$ respectively. Land was prepared and furrows were made at depth of $0.5 \mathrm{~cm}-1 \mathrm{~cm}$ and radish seeds were sown in rows. After five days of sowing, they were thinned out at $10 \mathrm{~cm}$ spacing within the plants and allowed 1 plant per hill. Each row consisted of sixteen plants. Population of radish was constant in all treatments. At five days after sowing of radish, furrows (depth of $0.5 \mathrm{~cm}$ $-1 \mathrm{~cm}$ ) were made according to field plan and seeds of vegetable amaranthus were sown in rows and covered with soil. After one week, they were thinned out at $5 \mathrm{~cm}$ spacing and allowed one plant per hill. Irrigation was done twice a day until second week and once a day upto harvest. Fertilizers were applied as recommended by the Department of Agriculture, Sri Lanka as shown in Table $\mathbf{1 .}$

Table 1. Fertilizer Application for Radish and Amaranthus Intercropping

\begin{tabular}{|c|c|c|}
\hline Fertilizer & $\begin{array}{c}\text { Basal Application } \\
\text { (kg/ha) }\end{array}$ & $\begin{array}{c}\text { Top Dressing } \\
\text { (kg/ha) }\end{array}$ \\
\hline \hline Urea & 90 & 90 \\
\hline Triple super phosphate & 110 & - \\
\hline Muriate of potash & 65 & 65 \\
\hline
\end{tabular}

Top dressing was applied three weeks after planting of radish. Hand weeding was done in second and fourth weeks after planting of radish. There were no pest attacks, but the incidence of fungus disease was identified. This was controlled by the application of fungicide (Captan). Other agronomic practices were done as recommended by Department of Agriculture, Sri Lanka.

Vegetable amaranthus and radish were harvested at 30 days and at 55 days after planting respectively and yields were measured. Land equivalent ratio (LER), area time equivalency ratio (ATER), crop performance ratio, gross return, cost of cultivation, net returns, cost-benefit ratio, monetary equivalent ratio and per day return were calculated by using following equations [10].

\section{A. Biological Indices}

\section{Land Equivalent Ratio (LER)}

The most basic tool that agricultural scientist generally employ to evaluate intercropping is the Land equivalent ratio (LER). The land equivalent ratio, divide the intercrop yield of radish by yield of its pure stand and add that to the intercrop yield of vegetable amaranthus divided by its yield of pure stand and so on.

\section{LER $=\quad$ Yield of intercrop radish + Yield of intercrop vegetable amaranthus \\ Yield of monocrop radish $\quad$ Yield of monocrop vegetable amaranthus}

\section{Area-Time Equivalency Ratio (ATER)}

Since land equivalent ratio does not take into account the time for which land is occupied by the component crops of 
an intercropping system, area-time equivalency ratio (ATER) was also determined.

ATER $=\frac{(\mathrm{La} \mathrm{ta}+\mathrm{Lb} \mathrm{tb})}{\mathrm{T}}$

Where, La, Lb - Partial LER

ta, tb - Duration of crop a and b

$\mathrm{T}$ - Duration of the whole intercrop system

\section{Crop Performance Ratio (CPR)}

$\mathrm{CPR}=$

$(\mathrm{Yia}+\mathrm{Yib})$

$$
(\mathrm{Pia} \times \mathrm{Ysa})+(\mathrm{Pib} \times \mathrm{Ysb})
$$

Where, Yia, Yib - Productivity in unit area in the intercrop $a$ and $b$

Ysa, Ysb - Productivity in unit area in the sole crop $a$ and $b$

Pia, Pib - Proportion of intercrop area sown with a and $\mathrm{b}$

By using the above equations, biological indices such as LER, ATER and CPR were calculated.

\section{B. Economic Indices}

\section{Gross Return}

In each treatment, yield was multiplied by the price per unit weight. For this calculation, farm gate price was taken in an account.

\section{Cost of Cultivation}

Cost of cultivation was calculated by sums of fixed cost and variable costs (seed, fertilizer, chemical, labour, electricity)

\section{Net Return}

Net return was calculated by subtracting cost of cultivation from gross return.

\section{Cost-Benefit Ratio}

Cost-benefit ratio $=$

Gross return

Total (variable) cost of cultivation

\section{Monetary Equivalent Ratio (MER)}

Monetary equivalent ratio $=(\mathrm{ra}+\mathrm{rb}) / \mathrm{Ra}$

Where, ra, rb - monetrary returns from $\mathrm{a}$ and $\mathrm{b}$

$\mathrm{Ra}$ - Highest sole crop monetary return

$\mathrm{ra}=\mathrm{Pa} \times \mathrm{Ya}$

$\mathrm{rb}=\mathrm{Pa} \times \mathrm{Yb}$

Where, $\mathrm{Pa}, \mathrm{Pb}$ - Prices of unit weight of crop $\mathrm{a}$ and $\mathrm{b}$

$$
\mathrm{Ya}, \mathrm{Yb}-\text { Yield of } \mathrm{a} \text { and } \mathrm{b}
$$

\section{Per Day Returns}

Per day returns $=$

Net returns

Cropping period
The calculated data were analyzed using SAS version 6.3 and means between treatments were compared using Duncan's Multiple Range Test at 5\% level.

\section{RESULTS AND DISCUSSION}

\section{A. Biological Indices}

\section{Land Equivalent Ratio (LER)}

One way to asses the benefits of intercropping is to measure the productivity by using land equivalent ratio. LER compares the yield of growing two or more crops together with yield from growing the same crops in pure stands. The idea behind intercropping is to capitalize on the beneficial interactions between crops while avoiding negative interactions. Essentially, the LER measures the effect of both beneficial and negative interactions between crops.

LER is shown in Table 2. The statistical analysis of data indicated that intercropping combinations had significant effect $(\mathrm{P}<0.05)$ on LER. T3 and T4 significantly varied from T5 and T6. However, no LER difference was observed among T3 and T4. Maximum and minimum LER of 1.31 and 1.16 were attained by $\mathrm{T} 3$ and $\mathrm{T} 6$ intercropping combinations, respectively. However, all the intercropping systems recorded high LER compared with monocropping. Similar finding is reported in okra and amaranth intercropping [11]. LER values exceeding unity indicates a yield advantages from intercropping compared with monocropping. LER of 1.31 (T3) indicated that the area planted to monocultures would need to be $31 \%$ greater than the area planted to intercrop for the two to produce the same combined yields. In this study, all intercropping showed advantages compared with monocropping.

\section{Area Time Equivalency Ratio (ATER)}

The ATER provides more a realistic comparison of the yield advantage of intercropping over that of sole cropping than LER as it considers variation in time taken by the component crops of different intercropping systems. In all the treatments, the ATER values were smaller than LER values (Table 2), indicating the over estimation of resource utilization in the latter. ATER is shown in Table 2. There were no significant differences $(\mathrm{P}>0.05)$ in ATER among treatments. It was high in T3 (1.15) followed by T4 (1.10). It suggests that all the treatments performed well in ATER. Higher values of ATER in intercropped treatments compared with monoculture may be attributed to efficient utilization of land, solar radiation, water, light and added fertilizer. When the difference between growth durations of component crops is substantial, time becomes an important element and ATER is considered to be a more appropriate index of efficient of the system [12].

\section{Crop Performance Ratio (CPR)}

Crop performance ratio is defined as the productivity of an intercrop per unit area of ground compared with that expected from sole crops sown in the same proportions [13]. A value of CPR greater than unity implies an intercrop advantages and a value less than unity an intercrop disadvantage. In this experiment, there were significant differences $(\mathrm{P}<0.05)$ among the treatments (Table 2). T3 and T4 significantly varied from T5 and T6. CPR ranged from 1.30 (T6) to 
1.71 (T4). In all intercropping treatments, it was higher than unity, showed intercrop advantages.

From these biological indices, we can suggest that all the tested intercropping treatments were biologically superior and also may be economically superior and all treatments were selected for economic evaluation.

Table 2. Biological Indices of Intercropping Treatments

\begin{tabular}{|c|c|c|c|}
\hline Treatments & LER & ATER & CPR \\
\hline \hline T3 & $1.31 \mathrm{a}$ & 1.15 & $1.60 \mathrm{a}$ \\
\hline T4 & $1.30 \mathrm{a}$ & 1.10 & $1.71 \mathrm{a}$ \\
\hline T5 & $1.18 \mathrm{~b}$ & 1.05 & $1.38 \mathrm{~b}$ \\
\hline T6 & $1.16 \mathrm{~b}$ & 1.06 & $* 30 \mathrm{~b}$ \\
\hline "F" test & $*$ & $\mathrm{~ns}$ & \\
\hline
\end{tabular}

Value represents mean \pm standard error of three replicates.

F test: - *: $\mathrm{P}<0.05$; ns: not significant

Means followed by the same letter in each column are not significantly different according to Duncan's Multiple Range Test at $5 \%$ level.

\section{B. Economic Indices}

\section{Gross Return}

In this experiment, gross return was calculated by using farm gate price. Farm gate prices of radish and vegetable amaranthus were Rs 20.00 and Rs 10.00 respectively in Sri Lanka. Considering the farm gate prices is better than the considering market price, because farm gate price provides the actual gross return which is received by the farmers. Gross return from radish and vegetable amaranthus intercropping is shown in Table $\mathbf{3}$. There were high significant differences $(\mathrm{P}<0.01)$ in gross return among the treatments.

Table 3. Gross Return from Radish and Vegetable Amaranthus Intercropping

\begin{tabular}{|c|c|}
\hline Treatments & Gross Return (LKR) \\
\hline \hline T1 & $785200 \mathrm{~d}$ \\
\hline T2 & $1078400 \mathrm{ab}$ \\
\hline T3 & $1135500 \mathrm{a}$ \\
\hline T4 & $1158700 \mathrm{a}$ \\
\hline T5 & $1016100 \mathrm{bc}$ \\
\hline T6 & $983700 \mathrm{c}$ \\
\hline F test & $* *$ \\
\hline
\end{tabular}

Value represents mean \pm standard error of three replicates.

F test: - **: $\mathrm{P}<0.01$.

Means followed by the same letter in each column are not significantly different according to Duncan's Multiple Range Test at $5 \%$ level.

Among intercropping, it was high in T4 followed by T3. Plant population of vegetable amaranthus was high in $\mathrm{T} 4$ and gross return was varied according to the vegetable amaranthus plant density and yield of radish. In monocropping system, gross return from vegetable amaranthus (T2) was higher than that from radish (T1). Based on the present results, vegetable amaranthus would be advocated as base crop due to higher gross return.

\section{Cost of Cultivation}

Cost of cultivation is a supplementary index to indicate the amount of capital resources needed to adopt a particular cropping system. There was high significant differences $(\mathrm{P}<0.01)$ among the treatment is shown in Table 4 . In this experiment, cost of cultivation was high in T4 followed T5. All intercropping increased cost of cultivation compared with sole cropping of radish (T1) and increase in the cost varied according to vegetable amaranthus density and fertilizer application in each treatment.

\section{Net Return}

Market value plays an important role than the number of crops per unit area and time in determine the economic returns. Net returns represent the actual income to the farmer. Net return used to evaluate economics of the sytem [12]. In this experiment, it was significantly varied $(\mathrm{P}<0.05)$ among the treatments is shown in Table 4. However, net return was high in all intercropping system compared with monocropping of radish. Among intercropping, T4 provided high returns followed by T3. Net return strongly correlated with vegetable amaranthus plant density and also monocropping vegetable amaranthus (T2) gave high returned in the present study.

\section{Monetary Equivalent Ratio (MER)}

Monetary equivalent ratio defined as the sum of the ratios of intercrop monetary returns to the highest sole crop monetary return from the entire land area occupied by all intercrops per unit time [14]. MER used to evaluate economic superiority of intercropping systems. There were significant differences $(\mathrm{P}<0.05)$ among intercropping. $\mathrm{T} 4$ significantly differed $(\mathrm{P}<0.05)$ fromT5 and T6. Among intercropping treatments, T4 provided high MER followed by T3 is shown in Table 4. It suggested that T4 would be the economic superiority system among intercropping treatments.

\section{Cost Benefit Ratio (C/B Ratio)}

Cost benefit ratio also named return per rupee invested or input out put ratio. This index provides an estimate of the benefit a farmer derives for the expenditure they incurred in adopting a particular cropping system. Cost benefit ratio was highly significant $(\mathrm{P}<0.01)$ among tested treatments (Table 4). Among the intercropping, it ranged from 10.67 (T4) to 9.20 (T6). High plant density leads to give high yield, It may be one of the reason for high $\mathrm{C} / \mathrm{B}$ ratio in $\mathrm{T} 2$.

\section{Per Day Return}

This gives the efficiency of the cropping system in terms of monetary value. Significant differences $(P<0.05)$ were observed in per day return. It was ranged from LKR 18497 (T4) to LKR 11861 (T1). High per day return in T4 may be due to high plant density.

\section{CONCLUSION}

The present results showed that all intercropping treatments performed well in LER compared with monocropping. It ranged from 1.31 (T3) to 1.16 (T6). In case of ATER, 
Table 4. Economic Performance of Different Treatments

\begin{tabular}{|c|c|c|c|c|c|}
\hline Treatments & Cost of Cultivation (LKR) & Net Returns (LKR) & MER & Cost-Benefit Ratio & Per Day Return (LKR) \\
\hline $\mathrm{T} 1$ & $1,20,970 \mathrm{e}$ & $6,64,230 \mathrm{c}$ & - & $7.35 \mathrm{~d}$ & $11861 \mathrm{c}$ \\
\hline $\mathrm{T} 2$ & $76,010 \mathrm{f}$ & $10,02,390 \mathrm{a}$ & - & $16.91 \mathrm{a}$ & 17899 a \\
\hline $\mathrm{T} 3$ & $1,21,970 \mathrm{c}$ & $10,13,530 \mathrm{a}$ & $1.05 \mathrm{ab}$ & $10.54 \mathrm{~b}$ & 18098 a \\
\hline $\mathrm{T} 4$ & $1,22,837 \mathrm{a}$ & $10,35,863 \mathrm{a}$ & $1.07 \mathrm{a}$ & $10.67 \mathrm{~b}$ & 18497 a \\
\hline $\mathrm{T} 5$ & $1,22,359 \mathrm{~b}$ & $8,93,741 \mathrm{~b}$ & $0.94 \mathrm{bc}$ & $9.39 \mathrm{c}$ & $15959 b$ \\
\hline T6 & $1,21,104 \mathrm{~d}$ & $8,62,596 \mathrm{~b}$ & $0.91 \mathrm{c}$ & $9.20 \mathrm{c}$ & $15403 \mathrm{~b}$ \\
\hline F test & $* *$ & $*$ & $*$ & $* *$ & $*$ \\
\hline
\end{tabular}

Value represents mean \pm standard error of three replicates.

F test: - *: $\mathrm{P}<0.05 ; * *: \mathrm{P}<0.01$.

Means followed by the same letter in each column are not significantly different according to Duncan's Multiple Range Test at $5 \%$ level.

there were no significant differences $(\mathrm{P}>0.05)$ in ATER among treatments. It was high in T3 (1.15) followed by T4 (1.10). ATER values were smaller than LER values in all intercropping treatments. There were significant differences $(\mathrm{P}<0.05)$ in $\mathrm{CPR}$ among the treatments. In all intercropping treatments CPR was higher than unity, demonstrating intercrop advantages. From these biological indices, we suggest that all the tested intercropping treatments performed well and may be economically superior. There were high significant differences $(\mathrm{P}<0.05)$ among the treatments in gross return. Among intercropping, it was high in $\mathrm{T} 4$ followed by T3. Compared with monocropping, cost of cultivation was high in intercropping. Among intercropping, it was high in T4 and low in T6. But net return was high in T4, due to high plant density of vegetable amaranthus. Cost benefit ratio was high in T2 (16.91). Among intercropping system, T4 (10.67) performed well in cost benefit ratio followed by T3 (10.54). In case of MER, it was high in T4 (1.07). Per day return was significantly differed $(\mathrm{P}<0.05)$ among the treatments. It was high in T4 followed by T3. However, there was no significant differences $(\mathrm{P}>0.05)$ between $\mathrm{T} 3$ and $\mathrm{T} 4$. The present study concluded that $\mathrm{T} 4$ would be the most biological and economical efficient system.

\section{REFERENCES}

[1] Anthony Y, Ezedinma FOC, Ochapa CO. Introduction to tropical Agriculture. Longman group U.K Ltd: England 1990; p. 1.
[2] Chatterjee BN, Maiti S, Mandal BK. Cropping system. Oxford and IBH publishing Co. Pvt. Ltd: India 1993; pp. 50-132.

[3] Depertment of Agriculture. Radish, 2006 Sri Lanka: ICTA; 2006 [Cited 2008, April 04]. Available from: http://www.agridept.gov. lk/Techinformations/Vege/Raddish/Radish.html

[4] Sandhu MK. Root Crops. In: Boss, Ed. Vegetable Crops. Naya Prokash, India 1993; pp. 470-88.

[5] Teutonico RA, Knorr D. Amaranth composition, properties and applications of a rediscovered food crop. Food Technol 1985; 39: 49-60.

[6] Tandon HLS. Fertilizer management in food crops, fertilizer development and consultation organization: India 1993; pp. 177-86.

[7] Saha SR, Nazimuddin M, Rahman MA, Sharifuzzaman SM, Anwar Habib AKM. Growth and harvestable maturity of red amaranth at different sowing dates. Asian J Plant Sci 2003; 2(5): 431-3.

[8] Fisher NM. Studies in mixed cropping. Exp Agric 1977; 13: 16977.

[9] Joshi M, Prabhakarasetty TK. Sustainability Through Organic Farming, Kalyani Publisher: India 2005; p. 310.

[10] Sivaraman K, Palaniappan SP. Cropping Systems in the Tropics Principles and Management, New Age International Ltd: India 1996; pp. 28-150.

[11] Susan AJ, Mini C. Biological efficiency of intercropping in okra (Abelmoschus esculentus (L.) Moench). J Trop Agric 2005; 43(12): 33-6.

[12] Ofori F, Stern WR. The combined effects of nitrogen fertilizer and density of the legume component on production efficiency in a maize/cowpea intercrop system. Field Crop Res 1987; 16: 43-52.

[13] Azam Ali SN, Mathews RB, Williams JH, Peacock JM. Light use, water uptake and performance of individual components of a sorghum/groundnut intercrop. Exp Agric 1990; 26: 413-27.

[14] Adetioye PO, Adekunle AA. Concept of monetary equivalent ratio and its usefulness in the evaluation of intercropping advantages. Trop Agric 1989; 66: 337-41. 